\title{
Mengukur Potensi Wirausaha pada Program Pelatihan Kewirausahaan Mahasiswa Pendidikan Ekonomi
}

\author{
Muhammad Rapii \\ Fakultas Ilmu Sosial dan Ekonomi, Universitas Hamzanwadi \\ mrapii166@gmail.com
}

\begin{abstract}
This study aims to to describe the potential entrepreneurs in the entrepreneurship training.The research results show that potential entrepreneurs in terms of various indicators show that the entrepreneurial potential students are in very high and high. categoryTo examine the potential owned, students need to realize how should students can develop the potential to have success in supporting activities. entrepreneurshipKnowledge of entrepreneurs have to support business success is only acquired to formal education in campus, but can also be obtained by, seminar activities training and. is self-taught

Keywords: Entrepreneurial Potential, Training Program on Entrepreneurship
\end{abstract}

\begin{abstract}
Abstrak
Penelitian ini bertujuan untuk menggambarkan potensi wirausaha pada program pelatihan kewirausahaan. Hasil penelitian menunjukkan bahwa potensi wirausaha dilihat dari berbagai indikator menunjukan bahwa tingkat potensi wirausaha mahasiswa berada pada kategori sangat tinggi dan tinggi. Untuk mengetahui potensi yang dimiliki mahasiswa, harus menyadari bagaimana sebaiknya mahasiswa dapat mengembangkan potensi diri yang dimiliki dalam menunjang keberhasilan kegiatan kewirausahaan. Pengetahuan tentang wirausaha dalam mendukung kesuksesan usaha tidak mesti hanya diperoleh dengan pendidikan formal di kampus, melainkan dapat juga diperoleh dengan kegiatan seminar, pelatihan dan otodidak.
\end{abstract}

Kata kunci: Potensi Wirausaha, Program Pelatihan Kewirausahaan

\begin{tabular}{|c|c|}
\hline \multirow{4}{*}{$\begin{array}{l}\text { Permalink/DOI } \\
\text { Cara Mengutip }\end{array}$} & http://dx.doi.org/10.32503/jmk.v4i2.487 \\
\hline & Rapii, Muhammad. (2019). Mengukur Potensi Wirausaha pada \\
\hline & m Pelatihan Kewirausahaan Mahasiswa Pendidikan \\
\hline & Ekonomi. JMK (Jurnal Manajemen dan Kewirausahaan), 4 (2), \\
\hline & 126-135 doi: http://dx.doi.org/10.32503/jmk.v4i2.487 \\
\hline Sejarah Artikel & $\begin{array}{l}\text { : Artikel diterima } 5 \text { April 2019; direvisi } 12 \text { April 2019; disetujui } \\
20 \text { April } 2019\end{array}$ \\
\hline
\end{tabular}

Alamat korespondensi :

Jl. TGKH Muhammad Zainuddin Abdul Madjid No. 132 Pancor

Fakultas Ilmu Sosial dan Ekonomi Universitas Hamzanwadi

Selong Kab. Lotim

Nusa Tenggara Barat 


\section{Pendahuluan}

Memasuki abad 21 di era global ini, persaingan dan tantangan semakin kuat. Tidak hanya persaingan tingat lokal, regional, dan nasional saja yang kita hadapi, tetapi persaingan global dari berbagai negara. Globalisasi telah menuntut kita untuk mengubah tatanan kehidupan dalam masyarakat dengan mempersiapkan dan membenahi sumberdaya manusia yang kita miliki agar mampu bersaing di pasar global. Dunia disekeliling kita terus berubah. Kita tidak lagi dapat menganggap kehidupan kita sebagai anugerah saja, tetapi harus berusaha memelihara dan memperjuangkannya secara aktif dalam ekonomi global yang semakin kompetitif. Oleh karena itu perekonomian dunia menawarkan tantangan dan kesempatan bagi siapa saja.

Dalam rangka pengembangan ekonomi nasional, maka koperasi sebgai badan usaha pada dasarnya yang perlu mendapat perhatian adalah bagaimana pemilihan sistem kelembagaan yang tepat yang lebih mendukung pengembangan aktivitas ekonomi dengan tujuan adanya keberpihakan kepada kesejahteraan masyarakat secara luas. Dengan kata lain, penekanan akan memperjelas jutifikasi pentingnya keberadaan bentuk badan usaha yang dikelola dari oleh dan untuk masyarakat. Hal ini sangat relevan dengan keberadaan koperasi. Pengembangan aktivitas ekonomi yang sesuai dengan konteks ini adalah aktivitas ekonomi yang juga bertujuan selain untuk meningkatkan nilai tambah sumber daya yang tersedia yang dikembangkan dengan pendekatan bisnis, juga aktivitas ekonomi yang berkembang ke arah terjaminnya partisipasi yang tinggi dari masyarakat. Dalam hal ini, bukan saja partisipasi dalam ikut serta menikmati hail pembangunan aktivitas ekonomi itu. Lebih jauh keberadaan koperasi dipandang penting jika pengembangan aktivitas ekonomi tersebut juga berwawasan ke arah untuk meningkatkan martabat dan harkat masyarakat baik secara langsung maupun tidak langsung. Dalam kaitaninilah pembahasan pengembangan koperasi menjadi sangat relevan serta perlunya komitmen dan dukungan yang kongkret dari berbagai pihak yang memiliki kompetensi, seperti dari perguruan tinggi dalam turut serta secara nyata mendukung pengembangan koperasi.

Pemerintah Indonesia sangat berkepentingan dengan Koperasi, karena Koperasi di dalam sistem perekonomian merupakan soko guru. Koperasi di Indonesia belum memiliki kemampuan untuk menjalankan peranannya secara efektif dan kuat. Hal ini disebabkan Koperasi masih menghadapai hambatan struktural dalam penguasaan faktor produksi khususnya permodalan. Dengan demikian masih perlu perhatian yang lebih luas lagi oleh pemerintah agar keberadaan Koperasi yang ada di Indonesia bisa benar-benar sebagai soko guru perekonomian Indonesia yang merupakan sistem perekonomian yang yang dituangkan dalam Undang-Undang Dasar 1945.

Cita-cita koperasi memang sesuai dengan susunan kehidupan rakyat Indonesia. Meski selalu mendapat rintangan, namun Koperasi tetap berkembang. Seiring dengan perkembangan masyarakat, berkembang pula perundangundangan yang digunakan. 
Perkembangan dan perubahan perundang-undangan tersebut dimaksudkan agar dapat selalu mengikuti perkembangan jaman

Kenyataan di lapangan menunjukkan, bahwa wirausaha di Indonesia, terutama pengusaha kecil dan menengah tumbuh berkembang dendgan jiwa wirausha yang diturunkan dari nenek moyang secara turun menurun, bukan melalui pendidikan formal. Data yang dikemukakan DP3M, Dirjen Dikti (1998) menyebutkan sekitar 34 juta pengusaha kecil yang terbesar di seluruh Indonesia, hanya 3-5\% berpendidikan tinggi dengan kurang dari 2\% diantaranya lulusan Diploma/Politeknik. Sekitar 75-85\% di antara pengusaha kecil tersebut paling tinggi adalah lulusan Sekolah Dasar. Selanjutnya juga dinyatakan bahwa pendidikan lebih banyak menghasilkan lulusan pekerja yang walaupun berpengetahuan tinggi, bukan wirausahawan yang dengan penguasaan ilmu dan teknologinya berusaha secara mandiri dapat mensejahterakan diri dan mensejahterakan masyarakat.

Berkaitan dengan pentingnya masalah kewriausahaan bagi perbaikan perekonomian negara, pemerintah telah mengeluarkan intruksi Presiden RI Nomor 4, tahun 1995 tentang gerakan nasional memasyarakatkan dan membudayakan kewiraushaan. Kemudian inpres ini ditindaklanjuti oleh Depdiknas, dengan diluncurkannya program pengembangan kewirausahaan ini dalam bentuk paket-paket pendidikan dan kegiatan bagi mahasiswa. Program ini merupakan bentuk dari kepedulian pemerintah dan Depdiknas terhadap masih tingginya tingakat pengangguran dikalangan terdidik khususnya lulusan perguruan tinggi, serta dalam rangka menjawab tantangan global. Pemerintah melalui Departemen Koperasi dan UKM juga telah mencanangkan program gerakan tunas kewriausahan nasional (Getuk Nasional) untuk mahasiswa. Seperti program pemerintah terdahulu, program ini merupakan gerakan penanaman jiwa kewirausahaan secara dini kepada mahasiswa dan khausunya masyarakat pemula yang akan melakukan kegaitan wirausaha.

Tabel 1. Pengangguran Terbuka

\begin{tabular}{|c|c|c|}
\hline No & $\begin{array}{c}\text { Pendidikan Tertinggi } \\
\text { yang Ditamatkan }\end{array}$ & 2009 \\
\hline 1. & $\begin{array}{l}\text { Tidak/Belum Pernah } \\
\text { Sekolah/Belum Tamat } \\
\text { SD }\end{array}$ & 2.620 .049 \\
\hline 2. & Sekolah Dasar (SD) & 2.054 .682 \\
\hline 3. & SLTP & 2.133 .627 \\
\hline 4. & SMA & 1.337 .586 \\
\hline 5. & $\begin{array}{l}\text { Diploma } \\
\text { I/II/III/Akademik }\end{array}$ & 486.399 \\
\hline 6. & Universitas & 626.621 \\
\hline & Total & 9.258 .964 \\
\hline
\end{tabular}

Sumber: Kemendiknas (2012)

Berdasarkan data yang tersaji dalam tabel di atas, terlihat bahwa angka pengangguran terbuka dari lulusan Unitversitas cukup tinggi. Lulusan Universitas memang jumlahnya lebih rendah daripada lulusan SLTP dan SMA, namun tetap mengisyaratkan bahwa pendidikan tinggi bukan jaminan mendapatkan pekerjaan dan tidak menganggur.

Menurut beberapa analisis, baik dari para akademisi maupun dari praktisi, kondisi seperti ini terjadi karena rendahnya mentalitas kewirausahaan lulusan (Alma, 2011). Mereka memiliki pola pikir pencari kerja dan bukan pencipta kerja. Hal ini sejalan dengan temuan Hermawan (2003) yang menyatakan bahwa permasalahan utama lulusan pendidikan adalah kemandirian 
pendidikan hanya menghasilkan sumber daya manusia yang bersemangat karyawan. Ouputnya diarahkan untuk menjadi pegawai atau bekerja untuk orang lain dan mendapatkan upah. Inilah inti masalah yang menyebabkan kemiskinan dan keterbelakangan bangsa Indonesia. Jumlah wirausaha di Indonesia masih sangat sedikit dan tentu saja masih sangat jauh dari kebutuhan

Tingkat

kemampuan

berwirausaha di Indonesia masih rendah bila dibandingkan dengan negara-negara di kawasan Asia Pasifik. Rasio antara jumlah wirausahawan dibandingkan dengan jumlah penduduk Indonesia hanya 1:83, sedangkan Filipina 1:66, Jepang 1:25, bahkan Korea kurang dari 20. Ditinjau berdasarkan rasio wirausahawan secara International, rasio yang ideal 1:20 (Yuyus dan Bayu, 2010). Untuk mengurangi angka pengangguran salah satu cara yang bisa dilakukan adalah dikembangkannya semangat entrepreneurship sedini mungkin. Hal ini disebabkan karena suatu bangsa akan maju apabila jumlah entrepreneur paling sedikit $2 \%$ dari jumlah penduduk. Pada tahun 2010 Indonesia memiliki sekitar 400.000 wirausahawan $0,18 \%$ dari jumlah penduduk. Bila rumusan $2 \%$ dari jumlah penduduk diperlukan untuk mencapai tingkat kemakmuran, maka Indonesia saat ini harus memiliki sekitar 4.600.000 wirausaha (Frinces, 2010).

Kenyatakan kondisi objektif lulusan perguruan tinggi tersebut sungguh memprihatinkan. Tuntutan golbalisasi dengan persaingan global dan pasar bebas, lapangan kerja yang semakin kompetitif, sementara itu banyak lulusan perguruan tinggi yang belum siap bekerja dan menunggu diberi pekerjaan. Kenyataan tersebut menunjukkan semakin perlunya tuntutan untuk membentuk sumberdaya manusia berkualitas, yang berjiwa wirausaha agar siap bersaing di pasar gelobal. Sumberdaya manusia yang berkualitas mempunyai keunggulan kompetitif dan komparatif (Weidy, 2009).

Dari kondisi objektif tersebut di atas semakin menunjukkan bahwa perguruan tinggi sebagai penghasil sumberdaya manusia berkualitas, dituntut untuk ikut berperan dalam pembangunan bangsa dan negara dengan membentuk manusia-manusia yang cerdas dan jiwa entrepreneur, mempunyai keunggulan kompetitif dan komparatif, sehingga bisa menang dalam persaingan global.

Berdasarkan permasalahan di atas maka strategi pengembangan koperasi sangat penting dalam rangka melatih mahasiswa untuk lebih optimal dalam mengembangkan kemampuan untuk berwirausaha.

\section{Tinjauan Pustaka}

Kewirausahaan merupakan suatu proses yang dinamika atau suatu rangkaian kegiatan yang dilaksanakan oleh para sntrepreneur di dalam usahanya untuk menghasilkan dan member nilai tambah bagi produk atau jasa tertentu yang telah diperjuangkannya dengan gigih sehingga berhasil mendapatkan keuntungan atau keberhasilan secara komersial.

Menurut instruksi Presiden RI No. 4 Tahun 1995, bahwa kewiraushaan adalah semangat, sikap, perilaku, dan kemampuan seseorang dalam mengenai usaha dan atau kegiatan yang mengarah pada upaya 
mencari, menciptakan, menerapkan cara kerja, teknologi, dan produk baru dengan meningkatkan efisiensi dalam rangka memberikan pelayanan yang lebih baik dan atau memperoleh keuntungan yang lebih besar.

Ronstad mengemukakan bahwa entrepreneurship merupakan sebuah proses dinamik dimana orang menciptakan kekayaan incremental. Kekayaan tersebut diciptakan oleh individu-individu yang menanggung risiko utama, dalam wujud risiko modal, waktu dan atau komitmen karier dalam hal menyediakan nilai produk atau jasa tertentu. Produk atau jasa tersebut mungkin tidak baru, atau bersifat unik, tetapi tetap nilai harus diciptakan oleh sang entrepreneur melalui upaya mencapai dan mengalokasi keterampilanketerampilan serta sumber-sumber daya yang diperlukan (Winardi, 2003)

Ciri-ciri seseorang yang memiliki jiwa wirausaha, yaitu(1) percaya diri, (2) berorientasi pada tugas dan hasil, (3) pengambilan resiko, (4) kepemimpinan, (5) keorisinilan dan (6) berorientasi ke masa depan (Alma, 2011). Manusia yang berjiwa wirausaha setidaknya memiliki kepribadian yang kuat, yaitu (1) Kepercayaan dan pengendalian diri pada saat mereka sedang melaksanakan pekerjaan, (2) selalu mencari aktivitas, (3) mampu mengendalikan diri, (4) mengelola pekerjaan berdasarkan tujuan, (5) penganalisisan kesempatan, (6) pemikiran yang kreatif dan objektif, (7) mamapu memecahkan persoalan (Mas'ud dan Mahmud, 2011).

Tabel 2. Spirit Entrepreneur

\begin{tabular}{|c|c|c|}
\hline Entrepreneur & $\begin{array}{c}\text { Spirit } \\
\text { Entrepreneurial }\end{array}$ & Keterangan \\
\hline kemandirian & $\begin{array}{l}\text { Locos of } \\
\text { Control } \\
\text { Kemandirian }\end{array}$ & $\begin{array}{l}\text { Spirit } \\
\text { entrepreneur } \\
\text { dibentuk oleh } \\
\text { sikap kemandirian }\end{array}$ \\
\hline
\end{tabular}

\begin{tabular}{|c|c|c|}
\hline & & $\begin{array}{l}\text { dan kendali diri } \\
\text { (Locos ofcontrol) } \\
\text { Internal yang } \\
\text { mantap }\end{array}$ \\
\hline Sikap Inovatif & $\begin{array}{l}\text { Kreativitas dan } \\
\text { Inovasi }\end{array}$ & $\begin{array}{l}\text { Kreativitas dan } \\
\text { inovasi } \\
\text { merupakan faktor } \\
\text { penentu } \\
\text { keberhasilan } \\
\text { dalam dunia } \\
\text { bisnis }\end{array}$ \\
\hline Sikap proaktif & Perencanaan & $\begin{array}{l}\text { Adanya } \\
\text { perencanaan dan } \\
\text { sikap proaktif } \\
\text { akan menjamin } \\
\text { kesuksesan dan } \\
\text { keunggulan dalam } \\
\text { banyak aspeknya }\end{array}$ \\
\hline $\begin{array}{l}\text { Pengambilan } \\
\text { risiko }\end{array}$ & $\begin{array}{l}\text { Pengambilan } \\
\text { risiko } \\
\text { Moderat }\end{array}$ & $\begin{array}{l}\text { Berani } \\
\text { menghadapi risiko } \\
\text { yang telah } \\
\text { diperhitungkan } \\
\text { adalah sikap } \\
\text { cermat dan cerdas } \\
\text { dalam bersaing } \\
\end{array}$ \\
\hline $\begin{array}{l}\text { Sikap berani } \\
\text { bersaing } \\
\text { Agresif }\end{array}$ & $\begin{array}{l}\text { Pengejaran } \\
\text { prestasi }\end{array}$ & $\begin{array}{l}\text { Pencapaian } \\
\text { prestasi dalam } \\
\text { persaingan yang } \\
\text { makin ketat } \\
\text { menjadi tujuan } \\
\text { utama para } \\
\text { entrepreneur }\end{array}$ \\
\hline
\end{tabular}

Sumber: Arman dkk ( 2007)

Hasil survey Lambing (2000) menunjukkan bahwa kebanyakan responden menjadi wirausaha karena didasari pengalaman yang membuatnya memiliki jiwa dan watak kewirausahaan. dari survey itu dapat disimpulkan bahwa untuk menjadi wirausaha yang berhasil, syarat utamanya adalah memiliki jiwa dan watak kewirausahaan. jiwa dan watak kewirausahaan dipengaruhi oleh keterampilan, kemampuan, atau kompetensi. Kompetensi sendiri ditentukan oleh pengetahuan dan pengalaman.

Untuk membantu membentuk tingkat keahliah dalam setiap bidang kecapakan, disajikan cirri-ciri kecakapan dalam daftar, yaitu sebagai berikut: (1) keuangan meliputi kemampuan untuk mengelola uang, menafsirkan laporan keuangan, dan 
mencari sumber dana; (2) pemasaran meliputi kemampuan mengindentifikasi pasar sasaran untuk produk dan jasa; (3) penjualan meliputi kemampuan merintis kunjungan penjualan dan menutup penjualan; (4) penembangan produk dan jasa meliputi menciptakan kampanye periklanan dan promosi yang berhasil dengan baik; (5) akuntansi meliputi kemampuan mencatat dan menafsirkan pendapatan dan pengeluaran; (6) manajemen personalia meliputi kemampuan untuk memperkerjakan orang-orang yang memenuhi kaulifikasi yang sesuai dengan pekerjaan dan mengawasi aktivitas kerja untuk mencapai produktivitas yang tinggi; dan (10) perencanaan bisnis meliputi kemampuan untuk mempertahankan dan mencapai tujuan jangka pendek dan jangka panjang yang telah ditetapkan.

\section{Bradstreet Business Credit}

Service menyatakan bahwa tingkat kompetensi yang harus dimiliki oleh seorang wirausahawan, yakni: (1) knowing your business, yaitu harus mengetahui apa yang harus dilakukan; (2) knowing the basic business management, yaitu mengetahui dasar-dasar pengelolaan bisnis, seperti bagaimana merancang, mengorganisasikan, memasarkan produk dan mengendalikan perusahaan; (3) having the proper attitude, yaitu memiliki sikap kesungguhan terhadap usaha yang dilakukan tidak setengah hati; (4) having adquate capital, yaitu memiliki modal yang cukup. Modal disini tidak hanya materi tetapi juga mental spiritual menyangkut keyakinan dan keteguhan hati sebagai modal utama dalam berusaha; (5) managing finances effectively, yaitu memiliki kemampuan mengatur keuangan secara efektif dan efisien; (6) managing time efficiently, yaitu kemampuan untuk mengatur waktu secara efisien dan tepat guna; (7) managing peopole, yaitu memiliki kemampuan untuk mengendalikan orang-orang dalam menjalankan perusahaan; (8) satisfying customer by providing high quality product, yaitu kemampuan untuk memuaskan pelanggan dengan memberikan pelayanan jasa atau barang yang bermutu; (9) knowing how to compete, yaitu mengetahui strategi bersaing dalam dunia usaha; (10) copying with regulations and paperwork, yaitu seorang wirausahawan harus memiliki kemampuan membuat aturan atau pedoman kerja yang jelas secara tertulis (Suryana, 2009).

\section{Metodologi Penelitian}

Penelitian ini menggunakan metode ex-postfacto. Penelitian expostfacto merupakan penelitian di mana variabel-variabel bebas telah terjadi ketika peneliti mulai dengan pengamatan variabel terikat dalam suatu penelitian (Sukardi, 2012). Pada penelitian ini, keterkaiatan antarvariabel bebas dengan variabel bebas, maupun antarvariabel bebas dengan variabel terikat, sudah terjadi secara alami, dan peneliti dengan setting tersebut ingin melacak kembali jika dimungkinkan apa yang menjadi faktor penyebabnya.

Pengukuran penilaian potensi diri dinyatakan dalam cara kualitatif yang tidak langsung yaitu dengan checklist items. Mahasiswa diminta untuk mengisi checklist items yang telah diberikan. Dari hasil pengisian checklist items kemudian dijumlahkan skor perolehan dari masing-masing item. Hasil 
penjumlahan yang menghasilkan skor total tersebut merupakan nilai potensi diri wirausaha. Untuk mengetahui nilai potensi diri wirausaha mahasiswa dilakukan dengan menyesuaikan pada pengkategorian yang telah ditentukan.

Penilaian potensi diri melalui beberapa tahap dengan menempuh langkah-langkah sebagai berikut.

1) Menentukan jumlah skor dari masing masing aspek yang diperoleh dari data tabulasi yang telah dilakukan terhadap hasil penyebaran kuesioner

2) Menjumlahkan nilai dari masing-masing aspek secara total.

3) Menterjemahkan nilai total yang diperoleh ke dalam pengkategorian potensi diri wirausaha.

4) Menganalisis dan menginterpretasikan hasil pengolahan data untuk selanjutnya dideskripsikan.

5) Pengambilan kesimpulan.

\section{Hasil \& Pembahasan}

Program pelatihan wirausaha merupakan salah satu program dalam sistem pembelajaran dan pendidikan yang ada di perguruan tinggi. Dengan demikian, program pelatihan wirausaha harus terintegrasi dan disinergikan dengan programprogram kewirausahaan yang telah ada seperti: kuliah kewirausahan, program kreativitas mahasiswa kewirausahaan, program magang, belajar bekerja terpadu, kuliah kerja usaha dan program kewirausahaan lainnya.

Kewirausahaan dimaknai sebagai semangat, sikap dan perilaku atau kemampuan seseorang dalam melihat peluang, menangani usaha dan atau kegiatan yang mengarah pada upaya mencari, menciptakan, menerapkan cara kerja, teknologi dan produk baru dengan meningkatkan efisiensi dalam rangka memberikan pelayanan yang lebih baik dan atau memperoleh keuntungan yang lebih besar. Kewirausahaan juga merupakan suatu proses kreativitas dan inovasi yang mempunyai risiko tinggi untuk menghasilkan nilai tambah bagi produk yang bermanfaat bagi masyarakat dan mendatangkan kemakmuran bagi wirausaha. Kewirausahaan itu dapat dipelajari walaupun ada juga orang-orang tertentu yang mempunyai bakat dalam hal berwirausaha. Program pelatihan wirausaha bertujuan untuk (1) membangun softskill atau karakter wirausaha; (2) menumbuh kembangkan wirausaha baru yang berpendidikan tinggi dan memiliki pola pikir pencipta lapangan kerja; (3) mendorong pertumbuhan, perkembangan atau terbentuknya kelembagaan (unit) pengelola program kewirausahaan di perguruan tinggi; dan (4) mendorong terbentuknya model pembelajaran kewirausahaan di perguruan tinggi.

Responden penelitian ini berjumlah 89 orang mahasiswa. Datadata karakteristik responden meliputi: pekerjaan orang tua, dan keinginan bekerja setelah lulus.

Table 3. Responden Berdasarkan Pekerjaan Orang Tua

\begin{tabular}{lcc}
\hline $\begin{array}{l}\text { Jenis pekerjaan } \\
\text { orang tua }\end{array}$ & $\begin{array}{c}\text { Frekuensi } \\
\text { (orang) }\end{array}$ & $\begin{array}{c}\text { Persen } \\
(\mathbf{\%})\end{array}$ \\
\hline Pegawai negeri & 9 & 10.1 \\
Pegawai Swasta & 6 & 6.8 \\
Pedagang & 12 & 13.5 \\
Guru & 16 & 18.0 \\
Ibu Rumah Tangga & 10 & 11.2 \\
Tani & 31 & 34.8 \\
Nelayan & 3 & 3.4 \\
Lainnya & 2 & 2.2 \\
\hline \multicolumn{1}{c}{ Jumlah } & $\mathbf{8 9}$ & $\mathbf{1 0 0}$ \\
\hline
\end{tabular}


Sumber: Data diolah (2018)

Berdasarkan tabel di atas sebagian besar responden berasal dari kalangan petani (34.8\%), kalangan pedagang $(13.5 \%)$. Sedikit sekali yang berasal dari kalangan pegawai negeri dan dari kalangan pegawai swasta. Latar belakang keluarga sangat mempengaruhi dalam menanamkan jiwa kewirausahaan seseorang. Mahasiswa yang berasal dari kalangan petani, pedagang, dan pengusaha biasanya mempunyai jiwa kewirausahaan yang lebih tinggi dibandingkan dengan anak-anak para pegawai negeri dan karyawan swasta. Keadaan ini menjadi potensi dalam pengembangan jiwa kewirausahaan mahasiswa.

Tabel 4. Responden Keinginan Berkerja Setelah Lulus

\begin{tabular}{lcc}
\hline Jenis pekerjaan & $\begin{array}{c}\text { Frekuensi } \\
\text { (orang) }\end{array}$ & $\begin{array}{c}\text { Persen } \\
\text { (\%) }\end{array}$ \\
\hline Wuraswasta & 30 & 33.7 \\
Pegawai Swasta & 7 & 7.9 \\
Pegawai BUMN & 2 & 2.2 \\
Pegawai Negeri Sipil & 43 & 48.3 \\
Dosen/Guru/Pendidik & 6 & 6.8 \\
Lainnya & 1 & 1.1 \\
\hline \multicolumn{1}{c}{ Jumlah } & $\mathbf{8 9}$ & $\mathbf{1 0 0}$ \\
\hline
\end{tabular}

Sumber: Data diolah (2018)

Berdasarkan tabel di atas, bahwa beragam alasan dikemukakan terkait dengan pilihan mahasiswa akan profesi yang paling mereka inginkan. Alasan menginginkan profesi wirausahawan disebabkan oleh beberapa alasan yaitu karena pendapatan yang lebih besar, sesuai dengan keyakinan, mutu pekerjaan yang lebih baik, lebih memberikan tantangan dan waktu tunggu mendapatkan kerja yang lebih singkat. Dari (33.7\%) responden yang menginginkan profesi wirausahawan sebagai pilihan mereka kelak, hal ini dikarena wirausahawan memiliki pendapatan yang lebih besar sedangkan alasan lainnya yang cukup dominan adalah karena image masyarakat terhadap pekerjaan ini lebih baik, mutu kerja yang lebih baik, lebih memberikan tantangan dan sesuai dengan harapan. Dari $(6.8 \%)$ responden yang menginginkan menjadi Pendidik beralasan bahwa image masyarakat terhadap pekerjaan ini lebih baik, mutu kerjanya lebih baik dan adanya kepastian pendapatan. Sedangkan mahasiswa yang menginginkan PNS paling banyak $(48.3 \%)$ sebagai profesi idaman beralasan karena image masyarakat terhadap pekerjaan ini lebih baik, adanya kepastian pendapatan, mutu kerja yang lebih baik, dan pendapatan yang lebih besar.

Rata-rata potensi wirausaha mahasiswa adalah sebesar 64.12 point yang dapat dikategorikan sangat tinggi. Artinya potensi wirausaha yang dimiliki oleh mahasiswa dapat dikategorikan sangat tinggi. Mereka menyimpan potensi yang sangat tinggi untuk menjadi seorang wirausaha jika dilihat dari sifat-sifat hakiki kewirausahaan yang mereka miliki.

Tabel 5. Kategori Pensekoran Potensi Diri Wirausaha

\begin{tabular}{|c|c|c|c|}
\hline $\begin{array}{c}\text { Rentang } \\
\text { Skor }\end{array}$ & Jumlah & $\begin{array}{c}\text { Frekuensi } \\
(\%)\end{array}$ & Kategori \\
\hline $15-34$ & 0 & 0,0 & Rendah \\
\hline $35-44$ & 0 & 0,0 & Sedang \\
\hline $45-59$ & 3 & 3,3 & Tinggi \\
\hline $60-75$ & 86 & 96,7 & $\begin{array}{l}\text { Sangat } \\
\text { tinggi }\end{array}$ \\
\hline $\begin{array}{c}\text { Total } \\
\text { rata-rata }\end{array}$ & $\begin{array}{c}89 \\
64.12\end{array}$ & 100 & $\begin{array}{l}\text { Sangat } \\
\text { tinggi }\end{array}$ \\
\hline
\end{tabular}

Sumber: Data diolah (2018)

$\begin{array}{rrrr}\text { Berdasarkan } & \text { tabel } 5 & \text { terlihat } \\ \text { bahwa } & \text { sebesar } & (96.7 \%) & \text { dari }\end{array}$


mahasiswa memiliki potensi wirausaha yang sangat tinggi dan sebagian lainnya yaitu $(3.3 \%)$ memiliki potensi wirausaha yang tinggi.

Hasil penelitian di atas dapat memberikan gambaran tentang seberapa jauh seseorang tersebut merasa dirinya perlu memperbaiki diri dan belajar agar lebih baik lagi. Mengenal diri sendiri berarti memperoleh pengetahuan tentang totalitas diri yang tepat, yaitu menyadari kelebihan yang dimiliki maupun kekurangan yang ada pada diri sendiri yang nantinya menjadi sumber kesuksesan dalam berwirausaha. Ada sepuluh hal yang harus dimiliki dan selalu diingat oleh seorang wirausaha sukses yaitu: (1) knowing your business, yaitu harus mengetahui apa yang harus dilakukan; (2) knowing the basic business management, yaitu mengetahui dasar-dasar pengelolaan bisnis, seperti bagaimana merancang, mengorganisasikan, memasarkan produk dan mengendalikan perusahaan; (3) having the proper attitude, yaitu memiliki sikap kesungguhan terhadap usaha yang dilakukan tidak setengah hati; (4) having adquate capital, yaitu memiliki modal yang cukup. Modal disini tidak hanya materi tetapi juga mental spiritual menyangkut keyakinan dan keteguhan hati sebagai modal utama dalam berusaha; (5) managing finances effectively, yaitu memiliki kemampuan mengatur keuangan secara efektif dan efisien; (6) managing time efficiently, yaitu kemampuan untuk mengatur waktu secara efisien dan tepat guna; (7) managing peopole, yaitu memiliki kemampuan untuk mengendalikan orang-orang dalam menjalankan perusahaan; (8) satisfying customer by providing high quality product, yaitu kemampuan untuk memuaskan pelanggan dengan memberikan pelayanan jasa atau barang yang bermutu; (9) knowing how to compete, yaitu mengetahui strategi bersaing dalam dunia usaha; (10) copying with regulations and paperwork, yaitu seorang wirausahawan harus memiliki kemampuan membuat aturan atau pedoman kerja yang jelas secara tertulis.

\section{Simpulan}

Berdasasrkan hasil penelitian di atas bahwa dalam menggali potensi wirausaha mahasiswa Program Studi Pendidikan Ekonomi dilihat dari berbagai indikator menunjukan bahwa tingkat potensi wirausaha mahasiswa berada pada kategori sangat tinggi dan tinggi. Untuk mengetahui potensi yang dimiliki mahasiswa, harus menyadari bagaimana sebaiknya mahasiswa dapat mengembangkan potensi diri yang dimiliki dalam menunjang keberhasilan kegiatan kewirausahaan. Pengetahuan tentang wirausaha dalam mendukung kesuksesan usaha tidak mesti hanya diperoleh dengan pendidikan formal di kampus, melainkan dapat juga diperoleh dengan kegiatan seminar, pelatihan dan otodidak.

Beberapa nilai-nilai

kewirausahaan yang dimiliki mahasiswa adalah sifat yang mau bekerja keras, penampilan yang baik, yakin, pandai membuat keputusan, mau menambah ilmu pengetahuan, ambisi untuk maju, pandai berkomunikasi, berkomitmen terhadap tugas, bertanggung jawab, minat kewirausahaan, peluang mencapai obsesi, energik, motivasi untuk unggul, berorientasi ke masa depan, mau belajar dari kegagalan. 


\section{Daftar Pustaka}

Arman, H. N., Bustanul, A., \& Moch., S. (2007).

Entrepreneurship (Membangun Spirit Teknopreneurship). Yogyakarta: Andi.

Buchari Alma. (2011).

Kewirausahaan untuk

Mahasiswa dan Umum.

Bandung: Alfabeta.

Frinces, Z. H. (2011). Be an Entrepreneur (Jadilah Seorang Wirausaha). Yogyakarta: Graha Ilmu.

Lambing. P., \& Kuehl, C. R. (2000). Entrepreneurship.

Upper

Saddle River: Prentice Hall.

Mas'ud Machfoedz dan Mahmud Machfoedz. (2011).

Kewirausahaan: Metode, Manajemen dan Implementasi. Yogyakarta: BPFE.

Sukardi. (2012). Metodologi Penelitian Pendidikan

Kompetensi dan Praktiknya. Jakarta: Bumi Aksara.

Suryana. (2009). Kewirausahaan Pedoman Praktis: Kiat dan Proses Menuju Sukses. Jakarta: Salemba Empat.

Wiedy Murtini. (2009) Kewirausahaan. Pendekatan Succes Story. Surakarta: SebelasMaret University Press.

Winardi. (2003). Entrepreneur dan Entrepreneurship. Jakarta: Prenada Media.

Yuyus, S., \& Bayu, K. (2010). Kewirausahaan Pendekatan Karakteristik Wirausahawan Sukses. Jakarta: Kencana Prenada Media Group. 